\title{
The teaching potential of case-technology in the formation of professional competences of university students
}

\author{
Natalia Berdnikova ${ }^{1, *}$, Natalia Abashina ${ }^{2}$, Elena Klimkina ${ }^{2}$, Nadezhda Manokhina $^{2}$, and \\ Svetlana Dudnikova ${ }^{1}$ \\ ${ }^{1}$ South Federal University, 344006, 105/42 BolshayaSadovaya Str., Rostov-on-Don, Russia \\ ${ }^{2}$ Don State Technical University, 344003, Gagarin sq., 1, Rostov on Don, Russia
}

\begin{abstract}
The article reviewed the theoretical and methodological aspect of the problem of forming professional competencies of University students in the process of using the pedagogical potential of casetechnology. The authors consider the case method as a unique technology used in the process of preparing students of special (defectological) education to work with children with special educational opportunities.
\end{abstract}

\section{Introduction}

Over the past decade, the Russian Federation has significantly changed the way in which teachers are trained for special (defective) education. An important task is considered to develop the professional competence of future teachers-defectologists, teachers-speech therapists, meeting the challenges of modern society. The process of developing the professional competence of students involves: the development of special skills in the cognitive, research, design, values, personal qualities, creating conditions for continuous improvement of professional skills in working with special children of different ages.

The draft "Professional standard"for teachers-defectologists considers as the main goal of professional activity: activities with students with disabilities, aimed at mastering the knowledge, skills and abilities necessary in modern society, providing correctional and pedagogical assistance; creating methodological support for the education process of people with special needs.

To achieve this goal, the teacher-defectologist must be able to:

- professionally organize the activities of persons with disabilities in the development of an adapted educational program.

- develop methodological support for an adapted educational program for people with disabilities at a high professional level.

- provide diagnostic and advisory assistance to persons with disabilities.

The process of forming professional competencies of University students involves the active use of interactive learning technologies by teachers, which certainly include case technologies.

\footnotetext{
"Corresponding author: PlatohinaN@yandex.ru
} 
Case technology is a unique technology that allows students to master the methods of problem-situational analysis. The main goal of this technology is to jointly analyze the case (problem situation) in detail by a group (subgroup) of students and develop a specific solution (strategy, model, etc.) the result of this technology is an algorithm for solving the described problem (plan, program, scheme, etc.).

The advantage of case technology in comparison with traditional pedagogical technologies is as follows:

- practical orientation (students learn to apply theoretical knowledge in practical activities);

- the obvious interactive format of the method (active participation in solving the case, emotional response to the problem, team spirit, group problem solving, etc.);

- personal-developing nature of interaction (students develop independence, mobility, ingenuity, rational character in decision-making, etc.).

Analysis of scientific literature showed that the use of case technologies in training by different authors was considered from different positions:

-in the writings ofBoblin, Sheryl L; Ireland, Sandra; Kirkpatrick, Helen \& Robertson, Kim describesexperience in using case technology in education, emphasizes that in the course of solving cases students learn to analyze information, identify problems, look for alternative solutions, and make a program of action [1];

- in Stewart Alison presents the experience of using case technology in the process of teaching students the skills to ask questions and build a strategy to answer them [2];

- in the publications of A. Dubois,F. Lind describes the experience of developing the leadership qualities of students in the process of solving cases. [3];

- in the writings of G.Easton, the problem of the use of case technology in the process of teaching college students is emphasized, emphasizes the practical orientation of the casemethod [4];

- A.M. Greenhalgh considers case technology as an effective method of training future professionals in different areas of life. [5],

- W. Wang in his work step-by-step described the teacher's guide to preparing cases [6];

- A.E. Richert's scientific publications are of particular interest to our research, in which $\mathrm{He}$ describes the experience of using case technology in the process of preparing future teachers for reflexive activity [7];

- P. Ammerman, A. Gawel, M. Pietrzykowski, R. Rauktiené, T. Williamson, M. A. Dyrud, A.Cameron presented the theoretical and practical aspect of using the case method in business education [8-10];

- J.A. Egskipe, M. R. Leenders, L. A. Mauffette-Leenders, A. Halinen in their publications described the technology of preparing cases for business school students [11-13];

- M. G. Monica, D. R. Hancock scientifically justified the use of the case method in working with students at different stages of training [14-15];

- strategy and model of social and professional training of future teachers-defectologists, experience of using interactive technologies in teaching students is presented in the Russian scientific publications of R. G. Aslaeva [16];

- the practice-oriented aspect of the use of case technology in the process of training future teachers is presented in the study of T.V.Sidorina, L.V. Shekhovtsova, scientists emphasize that this technology provides the process of mastering the necessary competencies by students [17];

- in the scientific publications of researcher H. M. Hajikurbanov, attention is focused on the possibility of using cases in the development of research competencies of students from a pedagogical University [18];

- in the works of M. Burava, a modern classification of case technologies is presented (structured cases, cases, video cases, mini-cases, etc. [19]. 
Consequently, the analysis of foreign and Russian studies allows us to formulate the following contradictions:

- between the proven pedagogical potential of the case technology and the lack of a scientifically based pedagogical model that constructs didactic conditions for the development of professional competence of students of special (defectological) education.

- between the need for University teachers to provide methodological support for the development of professional competencies of students of special (defectological) education and their insufficient development in the practice of modern education.

The methodological basis of this study was the following research approaches: competence approach in training specialists in the field of special education involves the shift from educational content on its result consists in mastering professional competences of students (I. A. Zimniaiaand others) [20];

- the active approach focuses on the use of interactive teaching methods and techniques in the learning process (S.MDzidzoeva., Z.P.Krasnoshlyk,N.N.Abashina, N.A. Platokhina, etc.) $[21 ; 22]$

- a systematic approach allows us to design a special didactic system for training specialists in the field of special (defectological) education (R.G. Aslayeva, N. V. Kuzmina,etc.) [23].

\section{The results of the research}

The analysis of psychological and pedagogical and special scientific literature, the practice in universities allowed us to formulate the purpose of the study: to identify the level of professional competence of students majoring inacademic program44.03.03 Special (defectological) education (3-4 years of training).

To achieve this goal, we used the following criteria for evaluating student's professional competence (according to T. L. Korzhenevich):

Table 1.Criteria for evaluating student's professional competence

\begin{tabular}{|l|l|}
\hline $\begin{array}{l}\text { Criteria for } \\
\text { evaluation }\end{array}$ & Assessment indicators \\
\hline motivational criteria & $\begin{array}{l}\text { norms, rules, ethics of the future } \\
\text { profession, the desire for self- } \\
\text { improvement, etc. }\end{array}$ \\
\hline cognitive criteria & $\begin{array}{l}\text { special knowledge about planning } \\
\text { and organizing work with a special } \\
\text { child, etc. }\end{array}$ \\
\hline operational criteria & $\begin{array}{l}\text { knowledge of effective } \\
\text { communication technologies with a } \\
\text { special child, methods and techniques } \\
\text { for correcting violations, etc. }\end{array}$ \\
\hline reflexive criteria & $\begin{array}{l}\text { self-analysis of their activities, results } \\
\text { of work with a special child, etc. }\end{array}$ \\
\hline
\end{tabular}

Diagnostic procedures (observation, discussion of problem situations, essays, portfolios) were selected in accordance with the specified criteria.

In our study, at the stage of the ascertaining experiment, 68 students of 3-4 courses majoring in academic program 44.03.03 Special (defectological) education took part. Quantitative and qualitative analysis of the results showed that $11.42 \%$ of students had a critical (unacceptable) level of professional competence (students experienced difficulties in the process of solving problem situations, planning correctional and educational activities with children with special educational needs, building a strategy for interaction of 
specialists in solving this problem, etc.); $74.78 \%$ of students had a basic level of professional competence (students are guided by current trends in the development of special education, have adequate methods and techniques for providing assistance to children with special educational needs, etc.); $9.34 \%$ of students were diagnosed with an intermediate level of competence (students are able to make decisions in typical standard situations that arise in the course of correctional and educational work with children with special educational needs, etc.). $4.46 \%$ of respondents identified a professional level of competence (students demonstrated readiness for non-standard solutions to professional problems, the ability to research, a high level of productivity in the process of completing the proposed tasks, etc.).

The research showed that future teachers-speech pathologists and speech therapists experience difficulties in monitoring the development of children with special educational needs (selection of methods and techniques, evaluation criteria, interpretation of results, etc.), in designing the correctional and educational process with children (formulation of achievable goals, tasks, planning results, selection of technologies, etc.), modeling the correctional and developmental environment of an educational institution (planning "zones", using modern interactive equipment, etc.).

Theobtained results allowed us to develop methodological tools for conducting practical and seminar classes with university students, majoring in academic program 44.03.03 Special (defectological) education (bachelor's degree) using cases.

We will give concrete examples of the use case-technology in the process of training students majoring in academic program 44.03.03 Special (defectological) education (bachelor's degree).

Case № 1: problem: complaints from the mother of a pupilfrom the 1st grade of a primary school about poor performance in the classroom, disobedience, restlessness, constant distraction during the task.

Initial data: complicated pregnancy, born prematurely (7 months); first steps in 1 year 8 months; first short words appeared in 3 years.

Rapid test of actual child development:

1. Establishing contact and behavioral characteristics: actively enters a conversation, greets first, the kid is open to conversation, also shows interest in the environment. Visual contact is stable. There is no constraint when communicating with a stranger. During communication, he does not keep a distance, comes close to the speaker, carefully looks at the lips, and monitors the speaker's articulation.

2. Specifics of speech and examination of the speech apparatus (articulation): speech is expanded, phrasal, with elements of lexical-grammatical and phonetic-phonemic underdevelopment. The kid's speech is poor, tongue-tied (good - not good, fun-not fun, etc.), fast, slurred, characterized with nasal pronunciation. Many sounds are missing or replaced. Pronounced asymmetry of nasolabial folds, difficulties with keeping the mouth closed, facial expressions are inactive. Features of the structure of the speech apparatus (articulation): teeth-malocclusion and fit; tongue-narrow, sedentary. Articulatory motility is impaired: movement of the jaw, tongue, and lips is difficult.

3. Large motor skills: coordination of movements is disrupted (jumps, squats are clumsy, with a fall). Gait shaky, unstable. The balance is unstable. Fine motor skills: movements are inaccurate, holding the handle or spoon incorrectly. Graph-motor skills are poorly developed. Mental processes: attention is extremely unstable, involuntary. Verbal and logical memory is reduced. Dominated by involuntary memorization. The amount of short-term memory is narrowed. The presence of abstract thinking. There is no critical attitude to errors.

Tasks:

1.What disturbance of development can you note in a particular child? 
2. What differential diagnosis should be done with the child?

3. Which specialists can be recommended to parents?

4. What learning and communication difficulties can be predicted in this child if the child's mother does not consider further speech correction necessary?

Case № 2: problem: teaching a child with a developmental disability.

Initial data: Vanya M. pupil of the 3rd grade of a primary school in the correction class. Autumn semester, at a Concilium attended by a speech therapist, a teacher - psychologist, a head teacher, and a class teacher, a complaint was received about the child's low academic performance, behavior, and lack of motivation. Over the past three months, Vanya has been treated by a neurologist, psychotherapy, and attended additional classes in English, Russian, and mathematics. Positive changes in the child's development began to be observed. For homework, he began to getA and $\mathrm{B}$ marks, for tests 2-3 points, for answers at the blackboard get $\mathrm{B}$ and $\mathrm{C}$ marks, sometimes $\mathrm{D}$. The school says that they will send the boy to psychological-medical-educational commission, and most likely, according to the Commission's conclusion, Vanya will go to a correctional school. The neurologist opposes the boy's education in a special educational institution.

Tasks:

1. Highlight and formulate the main issues raised in the text.

2. How would you title this text?

3. What are the characteristics of children aged 9-10 years? What is the role of communication with coeval in kid's age? Have you encountered similar situations? Give examples.

4. Give a reasoned answer and recommendations to parents questions: "What do you think is the best for parents to do? Go home-schooling? To take some time to study outside of the class, individually? Should after the summer holidays, go to the 4th grade?

Case № 3: problem: the mother of a 4-year-old childask for help the Children's development center.

Initial data: child aged 4 years and 7 months

Family: mother, stepfather.

Complaints: restlessness, excitability, absent-mindedness.

Examination conditions: in the game room, first in the presence of the mother, then without her.

Features of establishing and dynamics of contact in the examination situation: calmly enters the consultation room, does not respond to the greeting at the request of the mother, turns his head at the sound of his name, looks at the psychologist. Quickly adjusting, not paying attention to the conversation of adults, chooses your favorite toys, plays a battle with dinosaurs. Tentative research responses to items are preserved. Periodically approaches the psychologist with a question: "What is it?", - he answers: "Airplane" (so several times). Turns to an adult with an offer to play. The productivity of the game contact is quite stable. Visual contact is stable. Expressive and mimic means of communication are formed. The productivity of speech contact is somewhat reduced because of dysarthria. At the end of the class, she dances and sings with toys in her hands. Seeks to take your favorite toys with you, after a short persuasion, agrees to leave them and come to play later.

Features of behavior: insufficiently purposeful; characterized by a rapid change of activities and games due to increased distraction and excitability. Expresses his intention to build a garage for which he throws all the cubes out of the box on the floor; almost immediately gets distracted by the constructor, then throws it, and climbs with the toys into the house, where he plays out a quarrel between the dogs. He refuses to collect the scattered toys ("I am busy" - he said).

Joint activity with an adult at the time of the survey is organized against the background of stimulating, guiding and corrective assistance. At first, the child refuses to study ("I am 
tired, I can't, my leg hurts" - he said). But after a short game together, he agrees. Accepts help in full; requests help in case of difficulties.

The communicative sphere: the need to communicate a very clear, asking for a visit; prefer to have contact with older children. He is not afraid of unfamiliar adults, but does not show a desire to communicate, and shows interest in unfamiliar children. He is happy to meet familiar adults and children and invites them to play with him.

Affective sphere: the emotional background is unstable, there is emotional lability. Easily irritated or starts to get cranky if something does not work out; calms down quickly, immediately begins to laugh, inspired by a new game.

Psychomotor development: with some delay. Coordination of movements is insufficient (cannot catch the ball, but he is happy to kick it). Fine motor skills are not developed enough.

Graphicmotor skills are developed slightly below the age level. He refused to draw in the experiment. According to his mother, he likes to draw immediately after waking up or before going to bed, when he is in a calm state.

The leading activity: purposeful subject actions, the subject the game is formed. Culturally fixed actions mastered almost completely. A story game on everyday topics with characters is present. Game items are used for their intended purpose.

Cognitive development. Attention is extremely unstable, distraction is increased, and the volume is narrowed. With strong stimulation, concentration is available not only within the framework of the activity of interest, but also for a short time when working with didactic material.

Process of perception. Visual, auditory perception and somatosensory gnosis: without complaints and visible deviations. Reaction to bodily discomfort (hunger, thirst, urge to use the toilet): he notices bodily needs. Tactile sensitivity: no special features. Proprioceptive sensitivity: no special features.

Visual and effective intelligence was studied using the SeguinFormBoard, inserts: the child takes out the inset figures, tries to insert them not always in the appropriate holes. It receives help and then collects the mailbox itself. Actions are quite targeted, but not accurate, uses force instead of precise input. The task is completed with the help of an adult. Pyramid, cups: disassembles toys into parts, with little help collects taking into account the color and shape. The concept of shape and color is formed. Constructing actions are formed, interested in collecting from cubes, building a tower.

Speech: General underdevelopment of the third level of speech, violation of the pronunciation side of speech.

Expressive speech: does not pronounce all sounds, confuses syllables in words, does not always correlate case endings. Could make sentences out of 3-5 words. The voice modulates intonationally and reacts to the intonation-melodic side of the adult's speech. Onomatopoeia is present.

Impressive speech: fully understands the spoken language.

Profile of morpho functional asymmetries: right-handed.

Thus, there is a puerilism in cognitive development and speech development of mixed type; the child has signs of emotional and volitional instability (increased excitability, distractibility, lability, low level of arbitrariness). Rate delay of development for 1.5-2 years.

Tasks:

1. In what direction should you plan the correctional and developmental classes with the child? Justify your answer.

2. Advice of which specialists can be recommended to parents?

3. Make a schedule of classes for the child (the number and duration of classes per week). 
4. What methods and techniques of working with the family will be most effective? (write 5-7 recommendations for parents).

\section{Conclusion}

The results of a repeated diagnostic study of the level of professional competence in 68 students in the direction of training 44.03.03 Special (defectological) education showed that $6.34 \%$ of respondents had a critical level of professional competence; $61.2 \%$ of students had a basic level of competence (students showed a General orientation in the goals and objectives of their future professional activities); $7.45 \%$ had an intermediate level of competence (students were ready to act in typical, standard situations) and $25.01 \%$ had a professional level of competence (a high level of theoretical training, the ability to apply effective correctional and developmental technologies in practice, to act unconventionally, etc.). The results obtained allowed us to conclude that the use of interactive technologies, in particular, case technologies, is highly effective in the process of training future specialists to work with children with special educational needs, developing special skills in the cognitive, research, and project areas, values, and personal qualities, and creating conditions for continuous improvement of professional skills in working with special children.

\section{References}

1. L. B. Sheryl, S. Ireland, H. Kirkpatrick, K. Robertson, Using Stake's qualitative case study approach to explore implementation of evidence-based practice, Qualitative Health Research, 23(9), 1267-1275 (2013)

2. S. Alison, Case study, In Jane Mills \& Melanie Birks (Eds.), Qualitative methodology: A practical guide, 145-159 (CA: Sage: Thousand Oaks, 2014)

3. L. Aaboen, A. Dubois, F. Lind, Capturing processes in longitudinal multiply case studies, Industrial Marketing Managemen, 1, 235-246 (2012)

4. G. Easton, Critical Realism in Case Study Research, Industrial Marketing Management, 39(1), 118-128 (2010)

5. A. M. Greenhalgh, Case method teaching as science and art: A metaphoric approach and curricular application, Journal of Management Education, 31(4), 181-194 (2017)

6. W. Wei, Teaching Business English in China: Views on the case-based teaching in intercultural business communication, The Asian ESP journal, 7, 97-117 (2011)

7. A. E. Richert, Case methods and teacher education: Using cases to teach teacher reflection. In B. R. Tabachnick\& K. Zeichner (Eds), Issues and practices in inquiryoriented research, 130-150 (London, Falmer Press 2011)

8. P. Ammerman, A. Gawel, M. Pietrzykowski, R. Rauktiené, T. Williamson, The case study method in business education, 105-115 (BoguckiWydawnictwoNaukowe, Poznan, 2012)

9. A. Marilyn, DyrudUsing cases, Business Communication Quarterly, 62(1), 75-76 (2019)

10. C. Ann-Frances, The live teaching case: a new IS method and its application, Journal of Information Technology Education, 11, 7-42 (2012)

11. J. A. Erskine, Writing cases, Leenders, 4th ed. Ontario: Richard Ivey School of Business: University of Western Ontario, 190 (2011) 
12. A. E. James, Teaching with cases, London: Research and Publications Division: School of Business Administration: University of Western Ontario, 305 (2010)

13. A. Halinen, C. J. Medlin, T. Jan-AkeTime, Process in business network research, Industrial Marketing Management (2012)

14. M.G. Monica, A multivariate method for analyzing and improving the use of student evaluation of teaching questionnaires: a case study, Quality and Quantity, 45(6), 14151427 (2011)

15. D. R. HancockDoing, Case Study Research, 144 (London, Eurospan, 2012)

16. R. G. Aslayeva. Training of teachers-defectologists in pedagogicaluniversity: reality and perspective, Defectology, 2, 66-73 (2010)

17. T. V. Sidorina, L.V. Shekhovtsova, Synergetic effect the concept of innovative development, Humanities and Social Sciences in Europe: Achievements and Perspectives. Proceedings of the 11th International symposium (October 7, 2016). «East West» Association for Advanced Studies and Higher Education GmbH. Vienna, 112-118 (2016)

18. H. M. Hajikurbanova, Analysis of approaches to the classification of cases, World of Science, Culture, Education, 3(40), 9-11 (2013)

19. M. Buravoy, Facing an unequal world, Current Sociology, 63(1), 5-34 (2015) DOI: $10.1177 / 0011392114564091$

20. I. A. Zimnyaya, Scientist and practice, Personal education, 1, 68 (2016)

21. N. A. Platokhina, I. V. Samarina, N. N. Abashina, Preventive Measures of Speech Disorders in Early Childhood, Procedia Social and Behavioral Sciences, Annual International Scientific Conference Early Childhood Care and Education, ECCE 2016, 12-14 May 2016, Moscow, Russia, 233, 247-251 (2016)

22. N. A. Platokhina, S. M. Dzidzoeva, Z. P. Krasnoshlyk, The technology of familiarizing children of preschool age with the history of our homeland, Bulletin of the Southern Federal University, Pedagogical sciences, 6, 41-48. (2017)

23. N. V. Kuzmina, Acmeological factors in the development of the communicative culture of a teacher of a military educational institution, Actual problems of the humanities and socio-economic sciences, 11(8), 134-139 (2017) 